\title{
Ability as an Additional Support Need: Scotland's Inclusive Approach to Gifted Education
}

Margaret Sutherland ${ }^{* 1}$ AND Niamh STACK $^{2}$

$\approx$ The present paper provides an overview of the current national legislation, policies, curriculum and practice relating to gifted education within Scotland. It begins by providing an overview of the national context and historical background that, to this day, underpin the egalitarian ethos that permeates Scottish education. We discuss how historical, philosophical and political narratives that are firmly rooted in the belief that education is a right for all foreshadow Scotland's approach to "gifted education". The legislative shift within Scotland from a "needs-based" model to a "rights-based" model, coupled with our inclusive approach to education for all, has important implications and provides potential opportunities for gifted young people. The strengths and limitations of this approach are debated within the paper. Rhetoric and reality can, however, be unfamiliar strangers; the paper therefore also aims to demonstrate how legislative intention and pedagogical ideals have been put into practice within Scottish schools in order to meet the needs of gifted young Scots. We conclude by discussing the challenges that remain and the implications for the future, both within and beyond Scotland.

Keywords: inclusion, rights-based models, gifted education, Curriculum for Excellence, social justice

1 *Corresponding Author. Scottish Network for Able Pupils, University of Glasgow, Scotland, United Kingdom; Margaret.Sutherland@glasgow.ac.uk

2 Scottish Network for Able Pupils, University of Glasgow, Scotland, United Kingdom 


\section{Sposobnosti kot dodatna potreba: inkluzivni pristop $\mathrm{k}$ izobraževanju nadarjenih na Škotskem}

Margaret SutherLand ${ }^{*}$ in Niamh Stack

$\propto$ V prispevku so predstavljeni obstoječa nacionalna zakonodaja, politike, kurikulum in praksa na področju izobraževanja nadarjenih na Škotskem. Na začetku je predstavljen pregled nacionalnega konteksta in zgodovinskega ozadja, pri čemer lahko ugotovimo, da je bil vse do današnjega dne ves čas podprt etos enakopravnosti, ki je prisoten $\mathrm{v}$ škotskem izobraževanju. Sledi diskusija o tem, kako zgodovinska, filozofska in politična dejstva, ki so trdno zakoreninjena v prepričanju, da je izobraževanje pravica vseh, odlikujejo škotski pristop k »izobraževanju nadarjenih «. Zakonodajna sprememba modela, ki temelji na potrebah, za model, ki temelji na pravicah, ima skupaj z inkluzivnim pristopom $\mathrm{v}$ izobraževanju na Škotskem pomemben vpliv in zagotavlja priložnosti za nadarjene mlade. Analizirane so prednosti in omejitve tega pristopa. »Napisano « in realnost pa sta si lahko »nepoznana tujca«, zato je v prispevku predstavljeno tudi to, kako so bile v škotskih šolah zakonodajne namere in pedagoške ideje vpeljane $\mathrm{v}$ prakso, da bi zadovoljile potrebe nadarjenih mladih Škotov. V sklepu avtorji predstavijo izzive in predloge za nadaljnje usmeritve na Škotskem in širše.

Ključne besede: inkluzija, model, ki temelji na pravicah, izobraževanje nadarjenih, Kurikulum za odličnost, družbena pravičnost 


\section{The Scottish Education System}

Scotland is currently one of four nations that together form the United Kingdom of Great Britain and Ireland. We say currently, as on Thursday 18 September 2014 there will be a referendum on independence for Scotland, and depending on the outcome of this referendum this situation may change. Geographically, Scotland occupies the northern third of the British Isles and has a total population of 5.2 million (National Records of Scotland, 2014). Situated to the west of Europe, it is surrounded by seas on three sides. Although Scotland is currently part of both the UK and Europe, it is not part of England. England is a separate nation within the UK, yet the two countries are frequently mistakenly conflated in education texts. While commonalities exist between the two nations, there are nonetheless distinctive policies, legislative and practical aspects to Scotland's approach to education, not least to gifted education.

Scotland has an interminable tradition of universal state provision, and indeed Scotland has long seen education as a means to creating a robust democracy and a meritocratic social system (Devine, 1999). Compulsory education provision in Scotland consists of primary school education (age 5-12 years) and secondary school education (age 12-16/18 years). State-funded schools in Scotland are fully comprehensive, non-selective and coeducational. In addition to compulsory provision, preschool provision (age 3-5 years), further and higher education (post 18), and community education institutions exist. Political responsibility for education at all levels is vested in the Scottish Parliament and the Scottish Parliament and the Scottish Education and Enterprise, Transport and Lifelong Learning Department. Scotland is divided into 32 Local Education Authorities, and state schools are owned and operated by the authority in which they are geographically located. Overseeing and maintaining standards within these contexts rests with three main bodies:

1. Care Inspectorate - inspects care standards within preschool provision;

2. Education Scotland - inspects standards within preschool, primary, secondary, further and community education;

3. Quality Assurance Agency Scotland for Higher Education - this body safeguards standards and improves quality in higher education.

While the egalitarian nature of Scottish education is not without its critics (Mooney \& Scott, 2005), Scottish policy rhetoric is clearly aligned with such principles as social justice, egalitarianism, equality and human rights. One manifestation of this is a belief that, "with the exception of separate faith schools for Catholic children, all children should have access to a common curriculum in 
equally well-resourced schools" (Riddell, 2009, p. 288). Historical, philosophical and political narratives that are firmly rooted in the belief that education is a right for all therefore foreshadow Scotland's approach to "gifted education". In terms of curriculum, the shift away from a needs-based model towards a rights-based model has been gradual and is still on-going. However, the shift towards an inclusive system based on rights is evident in consequent policy and curriculum developments. A needs-based model suggests that special help for particular groups of children can best be provided when separate groups with common difficulties or issues are taught together. Once such groups have been provided for, the rest of the school population can be regarded as normal. In contrast, a rights-based model of education does not search for a group identifiable as different from the majority (Florian, 2008; Head \& Pirrie, 2007) but instead focuses on community and learning (Head, 2011). As such, the learning context becomes a focus for development and a means for developing a more just society in which difference and diversity are celebrated, not segregated. Gifted education in Scotland therefore sits within an overarching framework that seeks to ensure that education is about opportunities for challenge and the participation of all pupils. This helpfully directs us away from concerns about where and by whom gifted individuals should be taught and how they should be identified, instead focusing our attention on educational beliefs and values that must be applied equally to all learners (Smith, 2006). Although these intentions are honourable, their implementation depends on effective policy, legislation and practice.

\section{Scottish Policy and Legislation}

Policy development does not happen in a vacuum. As with many nations in the 21st century, the UK is a member state of a number of supranational organisations (for example, the European Union, the World Bank, the International Monetary Fund, the United Nations, the Organisation for Economic Cooperation and Development, etc.). These international bodies have influenced member states in numerous ways (Moutios, 2009). In relation to education in Scotland, a number of key international declarations have significantly influenced educational processes and systems. Article 26 of the United Nations Declaration of Universal Human Rights (UN, 1948) declares, "everyone has a right to education". In 1989, the United Nations Convention on the Rights of the Child (UNCRC) endorsed this and indicated that special assistance and care is important for childhood and development. In 1994, the Salamanca Statements (UNESCO, 1994) focused on educational equity for those with special educational 
needs. The intention is for the stances within these international policies to filter through to member state national documentation. Clearly there are potential dangers with such an approach, and critics such as Rizvi and Lingard (2006) and Moutios (2009) would argue that such bodies have promulgated the neoliberal agenda, resulting in the focus of many countries on "human capital development", where productivity and competitiveness within the global economy are crucial. Notwithstanding these concerns, there are clear parallels between the international discourse endorsed by these supranational bodies and policy development in Scotland. In terms of gifted education, there are two particular education acts that emerged from the international agenda and are helpful when considering the needs of the highly able. Firstly, the Standards in Scotland's Schools, etc. (2000) Act confirmed Scotland's commitment to an inclusive education system by asserting the right of every child to an education and introducing the assumption that pupils will be educated in mainstream schools unless exceptional circumstances apply. This Act enshrined the rights of all pupils in law by stating that education should be directed towards "the development of the personality, talents and mental and physical abilities of the child to their fullest potential" (Section 2), thus including the rights of highly able pupils.

The second helpful legislative development was the Education (Additional Support for Learning) (Scotland) Act 2004, updated in 2009 (Scottish Government, 2004, 2009). The Act replaced the term Special Educational Needs (SEN) with the term Additional Support for Learning (ASL), because it was felt that SEN had become too firmly associated with pupils who had disabilities and difficulties. This new term was accompanied by a new definition of what it meant to require "additional support". This Act states that "a child or young person has additional support needs for the purposes of this Act where, for whatever reasons, the child or young person is, or is likely to be, unable, without the provision of additional support, to benefit from school education provided or to be provided for the child or young person" (Section 1). This Act explicitly tied the education of able pupils into a reconceptualised special education arena. The Code of Practice (2005), which accompanied the Act, clarified this wider concept of additional support for learning: “... all children and young people benefit from school education when they can access a curriculum which supports their learning and personal development; where teaching and support from others meet their needs; where they can learn with and from their peers and where their learning is supported in the home and in the wider community" (Code of Practice, 2005, Section 2.2, p. 19). The Code went on to state four factors that might contribute to pupils requiring support: family circumstances, disability or health, the learning environment, and social 
and emotional factors. It helpfully added that "a need for additional support should not imply that a child or young person lacks ability or skills... more able children or young people may require a more challenging education provision than that of their peers" (Code of Practice, 2005, Section 2.6, p. 21). The updated act enhanced the rights of parents of all children who require additional support for learning, including those who are more able. In order to ensure that these rights are understood by parents and young people, the Scottish Government fund a helpline and website - Enquire (www.enquire.org.uk) - which offers helpful guidance and explanations of additional support for parents and young people. In 2012-2013, Enquire reported that $1 \%$ of their calls came from parents of highly able pupils; this does not, however, include details of web traffic to their website, as parents may also source information directly from there or from their children's schools. Situated within the University of Glasgow, the Scottish Network for Able Pupils (SNAP) works with Enquire to provide workshop training for staff, and Enquire regularly refer parents to SNAP staff and the SNAP website if parents have particular questions relating to high ability.

Funding for Additional Support for Learning is included in the block grant that the Scottish Government provides to all local authorities as part of the annual local government finance settlement. Each local authority is then allocated the total financial resources available to it on the basis of local needs and priorities, having first fulfilled its statutory obligations and the jointly agreed set of national and local priorities, including the Scottish Government's key strategic objectives. While this devolution of finance to local authorities offers autonomy to local areas, it could also mean that, in practice, groups of learners (particularly those who are perhaps misconceived as already advantaged) are overlooked, as competing priorities could lead to some groups missing out. However, providing challenge for more able children does not necessarily mean financial burdens; a great deal can be done with a curriculum that is both flexible and responsive.

\section{Curriculum Development}

Alongside the policy developments outlined above, the Scottish Executive launched a paper titled A Curriculum for Excellence: The Curriculum Review Group (2004, see Education Scotland 2011 for details of the documents). This new curriculum was designed to enable schools to develop their own content and pedagogy to meet perceived local needs, thus providing an appropriate curriculum for individual learners. It sought to make this available through a seamless curricular experience for pupils aged 3-18. Literacy, numeracy and 
health and wellbeing became the responsibility of all teachers at all levels, and, in general terms, the framework sought to offer teachers a more teacher-centred model of curriculum, thus moving away from the earlier prescriptiondriven genre. The accompanying descriptions of the curriculum express high expectations for all young people, stating that all Scottish pupils will become "successful learners, confident individuals, responsible citizens and effective contributors" (Scottish Executive, 2004b). Emphasis is placed on active learning (Scottish Executive, 2007), interdisciplinary learning, and planning across the curriculum (Scottish Government, 2008). There are five levels within the curriculum, with levels one to four having an associated set of experiences and outcomes for learning that aim to "recognise the importance of the quality and nature of the learning experience in developing attributes and capabilities and in achieving active engagement, motivation and depth of learning. An outcome represents what is to be achieved" (Learning Teaching Scotland (LTS), 2009, p. 3). Age and stage can be problematic where there is no flexibility (Sutherland, 2011); however, as stated in the curriculum guide, the levels "do not have ceilings, to enable staff to extend the development of skills, attributes, knowledge and understanding into more challenging areas and higher levels of performance" (LTS, 2009, p. 4). Thus, the apparent flexibility within the framework could be considered a particular strength when considering the needs of highly able pupils, as staff appear to no longer be tethered to the traditional chains of age and stage.

While Curriculum for Excellence is not without critique (Priestly \& Humes, 2010), it certainly seems to offer an ideal framework from which to construct appropriate learning opportunities for highly able pupils (Sutherland, 2011). However, theoretical concepts and admirable pedagogical intentions can be poles apart from the myriad of ways in which they are interpreted in practice in schools by a wealth of teachers with a diverse range of personal views on ability and how it is best challenged.

\section{Getting it Right for Every Child (GIRFEC)}

Having put in place policies, a curriculum framework and a raft of professional development opportunities for practitioners, the Government turned its attention to the needs of particularly vulnerable children. Getting It Right for Every Child (GIRFEC) was designed to ensure that all children receive appropriate and timely support when it is required. This would, it was believed, lead to all children developing the four capacities: making everyone an effective contributor, a successful learner, a responsible citizen and a confident 
individual (Scottish Government, 2006).

The GIRFEC approach, as it has become known, aims to bring together the support available to the individual child or young person from the family, the community and universal health and education services. The GIRFEC document acknowledged that the coming together of such support structures called for a shared understanding among the professionals involved. Moreover, it argued that shared tools and models would also help practitioners to meet the needs of individuals and their families. In order to facilitate this shared understanding, it proposed that a lead professional be appointed to coordinate the support available to the child and his/her family. This proposal was accepted, and was passed in the recent Children and Young People's Act (Scottish Government, 2014).

In an educational context, collaboration emerges from social constructivism theory. It relates to the work of Bruner (1996), who postulates that learning is about understanding the minds of others, and to the work of Vygotsky (1978), who put social interactions at the heart of the learning process. "The language of collaboration has entered into and been accepted within public and professional discourse in Scotland" (McCulloch, 2010, p. 165), and is evident within the GIRFEC document. It can, however, be difficult to achieve a level of deep collaboration when diverse individuals come together with their own agendas, experiences and outlooks on the world (Head, 2011).

In acknowledgement of the difficulties of collaborative working, and with an awareness of the collective knowledge base methodology, the GIRFEC approach offered a practice model that could be used in a uni- or multi-based agency context. It was designed to ensure that information about young people was collected in a consistent fashion, arguing that this would allow the agencies involved to develop a shared understanding of what support is required and a greater awareness of any "concerns that may need to be addressed" (Scottish Government, 2008, p. 21).

Following a national review of teacher education (Scottish Government, 2010), the Teaching Scotland's Future report made it clear that the teacher was a key contributor to effective learning and teaching. Thus, "teacher education should be seen as and should operate as a continuum, spanning a career and requiring much better alignment across and much closer working amongst schools, authorities, universities and national organisations" (Donaldson, 2012). In parallel with these developments, the Scottish Teacher Education Committee set up a working group to develop the National Framework for Inclusion (2010). This framework was designed to offer support and guidance to students and teachers as they seek to develop inclusive practice. It is currently 
being updated to reflect the changes to the career-long professional development landscape. As with other documentation, this framework develops the idea of inclusive practice through a series of questions that relate to the new, updated standards for teaching (Scottish Government, 2012). The staff that produced the framework brought together a range of specific expertise. A director of the Scottish Network for Able Pupils was one of the experts involved in this working group, which ensured that high ability was represented within this forum on inclusion.

At the heart of these policies and legislation is a desire to ensure that all Scottish pupils have access to appropriate and challenging learning experiences. Thus, in Scotland, "gifted learners" are part and parcel of the policy architecture; the intention is for them not to be segregated out for particular attention any more than any other group of learners.

\section{Practice from Scottish Schools and Authorities}

Education Scotland is the national body in Scotland responsible for supporting quality and improvement in learning and teaching from early years to adult and community learning. Teachers can access materials, resources and publications online and use these to inform planning and development. The Education Scotland website contains information about universal support; in other words, appropriate support for all learners, ensuring that they receive challenging and appropriate activities. It also contains information about additional support for learning, in areas where learners might require targeted support. Highly able pupils are mentioned in the following section of the website: (http://www.educationscotland.gov.uk/supportinglearners/additionalsupportneeds/index.asp).

One of the dangers of compartmentalising support in this way is that resources and activities that sit under another label or banner (e.g., critical thinking skills) will be overlooked by a busy teacher searching for appropriate resources and materials for "highly able pupils" simply because it does not bear the label "highly able pupils".

In 2012, the Scottish Network for Able Pupils conducted telephone interviews across thirteen local authorities in Scotland (Stack \& Sutherland, 2014). As part of this study, local authorities were asked about the provision available for highly able pupils. Authorities reported a range of extracurricular activities that were on offer in schools across Scotland. While very few were labelled or aimed specifically at pupils with high ability, the opportunities on offer were clearly appropriate for some highly able pupils. Activities included: 
- $\quad$ Additional music opportunities, e.g., guitar lessons in which primary school staff liaised with secondary staff and pupils;

- The Duke of Edinburgh Award;

- Outdoor education;

- $\quad$ Youth achievement;

- $\quad$ Supported study clubs;

- $\quad$ Specific subject tuition, e.g., National Youth Orchestra, film and media classes, drama, sports coaching, music tuition;

- $\quad$ Early access courses, e.g., Distance Education courses, activities at the University of Aberdeen;

- $\quad$ Extended work experience placements;

- Interschool collaborations to meet the needs of particular groups of children, as there was a dearth of Saturday clubs available to pupils in some geographical areas;

- University visits, e.g., advanced higher art, an arts-based project relating to fashion design, visual art and music.

In addition to the extracurricular and out-of-school activities outlined above, authorities reported a range of practices that were on offer in schools; for example, they spoke about the revolving-door approach to activities (where children joined other classes for some activities and then returned to their own class), working with older peers, and working in groups or individually. Irrespective of the variety of approaches, all of these activities still took place within the mainstream school. Some pupils worked across schools - for example, primary pupils working on standard grade mathematics in a secondary school - while others had links to colleges and universities. One authority made reference to the specialist school provision available in Scotland, e.g., The Dance School of Scotland, The Glasgow School of Sport, and specialist music tuition. This specialist provision makes available alternative educational routes that are specialised but located within mainstream schools. One authority felt that mainstream schools were generally excellent at looking creatively at provision for highly able pupils. They believed that the flexible nature of Curriculum for Excellence (CfE) lent itself to this creative way of working with a range of different learning needs. CfE was perceived to offer opportunities for curriculum development work across different ages and stages. Cooperative learning was not perceived as being restricted to particular year groups, thus offering the opportunity for pupils to work across year groups.

These findings regarding the diversity and creativity of provision are replicated in the work conducted more widely by the Scottish Network for Able 
Pupils (SNAP) in its work with teachers, schools and authorities across Scotland. In particular, SNAP works closely with five local authorities. In partnership with these authorities, a network of Associate Tutors has been established. The tutors act as a focus for the expansion of staff development, policy and provision at a local level, and are part of an on-going collaborative programme of staff development with SNAP staff at the University of Glasgow. They have built up considerable expertise and have been at the forefront of developments for highly able pupils within their authority. These staff development opportunities are open to all teachers. Costs are kept to a minimum, reflecting an appreciation of the fact that budgets have been cut as a result of the recent financial crisis; anecdotally, however, staff report a lack of supply teacher cover to release them from class as the main reason making attendance problematic. In order to address these restrictions, SNAP provides podcasts of conferences and seminars for Associate Tutors; there is also a virtual learning environment available, enabling remote access to resources.

SNAP has also worked with particular local authorities on specific projects. These projects have sought to incorporate aspects of research, policy and practice in the Scottish context. Crucially for SNAP, although these projects have sometimes taken place at the University of Glasgow or in contexts outside of school (e.g., museums), they have always been accompanied by a staff development element, thus building capacity within the profession and extending the session beyond a "one-off experience" for the young people attending. SNAP is keen to develop ways to address "practical problems in the lived professional lives on teachers" (Groundwater-Smith, 2007, p. 60). An example of such an approach is a project that considered ways to increase challenge in the curriculum, which brought together 21 members of teaching staff from one local authority, as well as a local authority staff representative. The group of teachers included four early years practitioners from five different settings, twelve primary school teachers or Additional Support for Learning coordinators within the primary context from eight different settings, and five secondary school teachers from four different settings across the authority. The sectors worked together to develop and implement programmes in their respective institutions. To conclude the project, SNAP hosted a dissemination event during which pupils visited the University of Glasgow and participated in a range of activities provided by university staff, including archivists, a graduate attribute advisor, PhD students, a Professor of Geography, a Senior Education Lecturer and a biologist. The local authority has reported that the schools involved are now embedding such pedagogical approaches in their learning and teaching, and that the programme is being rolled out across the authority. This approach 
raised awareness about highly able pupils among teachers and authority staff through expert input from SNAP staff, leading in turn to class- or school-based curricular developments that are an integral part of the learning and teaching process.

\section{Scotland's Approach to Supporting High Ability: Strengths, Weaknesses, and Opportunities}

Egalitarianism runs like a fine gossamer thread through the development of the Scottish education system. The current focus on inclusive education discussed in previous sections is congruent with this approach. However, no system is perfect, and inclusive education, with its roots in social justice and rights, has understandably caused tensions within a system concerned with needs. Head (2011) draws interesting comparisons between practice in special schools and practice in mainstream schools. He argues that, in Scotland, the move towards inclusion has created a greater diversity of learners in special schools and units that traditionally taught pupils with similar difficulties, e.g., moderate learning difficulties, autism, etc. As a result of this change in the school population, teachers have "responded by extending their repertoire of teaching skills" (Head, 2011, p. 62). The social context teachers find themselves in as a result of inclusion might in fact offer them an opportunity to develop an inclusive pedagogy, a pedagogy that is advantageous for highly able pupils. Inclusive pedagogy is grounded in practice, a practice that takes cognisance of the individuals within it, including the pupil and the teacher. A pedagogical approach that acknowledges and endorses what the learner brings to the learning context will result in a complementary pedagogy that allows for development. Significantly, an inclusive pedagogical approach for highly able learners moves us away from the debate about place and provision, focusing instead on teaching and learning. The fact that, in Scotland, legislatively, highly able learners sit side by side with those traditionally considered to have Special Educational Needs is helpful if we are to actualise this shift in focus. The national curriculum framework guide, Curriculum for Excellence, which is about providing a "coherent, flexible and enriched curriculum for all", is supportive of highly able learners. It would seem that, in terms of legislation and curriculum, Scotland is well situated to offer appropriate learning experiences for highly able pupils.

Change within systems does, however, need time to take root and evolve. Schon (1983) claimed that systems based on needs would impinge on teachers as they sought to adopt more inclusive practice, while Smith $(2006$, p. 17) argued that "in the case of Scotland it is too early to tell" whether the system is 
moving away from a reductionist, needs-based model. Eight years and one international financial crisis later, it still seems too early to tell, as the recent focus has been on how to ensure quality educational provision in times of austerity, and the bigger ideals have therefore been (hopefully temporarily) marginalised.

One weakness of this inclusive approach to high ability, or any other label for that matter, is that by subsuming learners into generic discussions about learning and teaching there is a potential to overlook particular requirements that certain learners may have. It also brings into sharp focus the policy/ practice nexus and places the teacher centre stage when it comes to providing effective learning opportunities. Knowledge about, and attitudes towards, highly able learners is likely to affect provision (Sutherland, 2011). The generic trap will only ensnare highly able learners if teachers approach the curriculum without giving due regard to this group of pupils and their learning. Scotland's Framework for Inclusion and its commitment to career-long professional development offers opportunities for teachers to develop pedagogy, assuming that teachers engage with such opportunities. The central role assumed by teachers in the learning and teaching process underpins SNAP's work through schooland class-based initiatives.

\section{Conclusion}

A fundamental principle in education must be about promoting social justice. Gifted education is often mistakenly equated with constructs of elitism (Sapon-Shevin, 2000) and thus not readily associated with such a principle. However, we know that gifted young people exist in all strata of socioeconomic status. Equally, we know that education does not exist in a vacuum. Highly able learners cannot be considered in isolation from other learners, and, in the case of those with double and multiple exceptionalities, their ability cannot be considered in isolation from their other challenges. It is here that the focus on rights offers some hope. The focus on rights has implications for opportunities for all young people, and placing the rights of the highly able in the debate necessarily moves us towards a discussion about pedagogy.

Similarly, education cannot be considered in a vacuum. Internationally, education is caught in a web of comparison (for example the PISA study). These comparisons assume a common baseline and fail to take cognisance of different educational structures and ethos. We need to ensure that these comparisons lead to meaningful and context-appropriate developments, and not to an unsatisfying shift towards an uncommon middle. Surely, if we have learnt anything from inclusive practices and gifted education, it is that difference can, 
and should, be valued. This is true of young people's abilities, just as it is true of educational approaches that are embedded in culture, context and history.

\section{References}

Devine, T. M. (1999). The Scottish nation, 1700-200o? London: Allen Lane.

Donaldson, G. (2013). Teaching Scotland's Future . Retrieved 3 April 2014 from http://www.scotland. gov.uk/Publications/2011/01/13092132/6

Florian, L. (2008). Special or inclusive education: future trends. British Journal of Special Education, 35(4), 202-208.

Groundwater-Smith, S. (2007). Questions of quality in practitioner research. In P. Ponte \& B. H.

Smit (Eds.), The Quality of Practitioner Research: reflections on the position of the researcher and the researched. Rotterdam: Sense Publishers.

Head, G., \& Pirrie, A. (2007). The place of special schools in a policy climate of inclusion. Journal of Research in Special Educational Needs, 7(2), 90-96.

Head, G. (2011). Inclusion and Pedagogy. In M. McMahon, C. Forde, \& M. Martin (Eds.),

Contemporary Issues in Learning and Teaching. London: SAGE Publications.

McCulloch, M. (2011). Interprofessional Approaches to Practice. In M. McMahon, C. Forde, \& M.

Martin (Eds.), Contemporary Issues in Learning and Teaching. London: SAGE Publications.

Mooney, G., \& Scott, G. (Eds.) (2005). Exploring social policy in the 'new' Scotland. Bristol, UK: Policy Press.

Moutious, S. (2009). International organisations and transnational education. Compare, 39(4), 469481.

National Records of Scotland. Retrieved from http://www.nrscotland.gov.uk

Riddell, S. (2009). Social justice, equality and inclusion in Scottish education. Discourse: Studies in the Cultural Politics of Education, 3o(3), 283-296.

Priestley, M., \& Humes, W. (2010) The development of Scotland's Curriculum for Excellence: amnesia and déjà vu. Oxford Review of Education, 36(3), 345-361.

Sapon-Shevin, M. (2000). Gifted education. In D. A. Gabbard (Ed.), Knowledge and power in the global economy. Politics and the rhetoric of school reform. Mawah, NJ: Lawrence Erlbaum.

Schon, D. A. (1983). The Reflective Practitioner: How professionals think in action London: Temple

Smith

Scottish Executive. (2004). A Curriculum for Excellence: the curriculum review group. Edinburgh: HMSO.

Scottish Executive. (2006). Building the Curriculum 1: the contribution of curriculum areas.

Edinburgh: HMSO.

Scottish Executive. (2007). Building the Curriculum 2: active learning in the early years. Edinburgh: HMSO.

Scottish Government. (2000). The Standards In Scotland's Schools etc (Scotland) (2000) Act. 
Scottish Government. (2004). The Additional Support for Learning (Scotland) (2004, 2009) Act. Scottish Government. (2010). Teaching Scotland's Future.

Smith, C. M. M. (2006). Principles of inclusion: implications for able learners. In C. M. M. Smith (Ed.), Including the Gifted and Talented: Making inclusion work for more gifted and able learners. London: Routledge.

UNESCO. (1994). The Salamanca Statement and Framework for Action on Special Education. Paris:

UNESCO. Retrieved 30 October 2010 from www.unesco.org

\section{Biographical note}

MARgaret Sutherland, Dr., lectures in additional support for learning at the University of Glasgow, Scotland. She is the Director of the Scottish Network for Able Pupils and Deputy Director of the Centre for Research and Development in Adult and Lifelong Learning. She has 33 years teaching experience in schools and higher education. She has written in the field of gifted education and is author of a number of academic papers, chapters and books. She speaks at conferences and has worked across the UK and with staff and students in Tanzania; Malawi; Korea; Virginia, USA; Slovenia; The Netherlands; Poland and Denmark.

Niamh Stack, Dr., lectures in Developmental Psychology in the School of Psychology at the University of Glasgow and is the Development Officer for the Scottish Network for Able Pupils which is also situated in the University of Glasgow (SNAP - http://www.gla.ac.uk/schools/education/ablepupils/). As part of her work in SNAP she is involved in supporting professional knowledge exchange partnerships with Scottish Education Authorities through providing continuing professional development activities to teachers focused on gifted development. She is also actively engaged in research and publication activities related to the development and education of children with high abilities. 